\title{
SOME XENIID ALCYONARIANS FROM JAPAN AND ADJACENT LOCALITIES
}

\section{$\operatorname{AUTHOR}(S)$ :}

Utinomi, Huzio

\section{CITATION:}

Utinomi, Huzio. SOME XENIID ALCYONARIANS FROM JAPAN AND ADJACENT LOCALITIES. PUBLICATIONS OF THE SETO MARINE BIOLOGICAL LABORATORY 1950, 1(3): 81-91

\section{ISSUE DATE:}

1950-10-05

URL:

http://hdl.handle.net/2433/174440

RIGHT: 


\title{
SOME XENIID ALCYONARIANS FROM JAPAN AND ADJACENT LOCALITIES*
}

\author{
Huzio UTINOMI
}

With 3 Text-figures

Very little of the Alcyonarian fauna of Japan has been investigated. We have only two records of the occurrence of species belonging to the family Xeniidae from our seas, namely Suensonia mollis recorded by BRUNDIN (1896) from Korea Strait, obviously a member of Cespitularia, and Anthelia japonica recorded by KüKENTHAL (1906) from Suruga Bay, as belonging to Cornulariidae. The present paper deals with a small collection of Xeniid alcyonarians, and is intended to contribute something to our present meagre knowledge on the Alcyonarian fauna of Japan and neighboring waters.

Seven species belonging to four genera have come to my examination, of which one seems to be new to science. The majority, with a single exception, were collected by myself from various places in Japan, Formosa and Palao.

I express my gratitude to Dr. T. KomaI for his kind guidance and incessaut encouragement as well as for the gift of valuable specimens obtained by him. The expense was defrayed out of a grant from the Japan Society for the Promotion of Scientific Research.

\section{Genus Anthelia SavignY (1817)}

The genus Anthelia has been frequently confused with Clavularia or Sympodium owing to the inadequacy of the original description of the type, as well as the incomplete definition of the genus. It has been referred to the Cornulariidae in the Stolonifera by most of the earlier workers. Recently GollAR (1939, 1940) transferred it to the Xeniidie in the Alcyonacea, mainly on account of the non-retractility of the polyps, the more or less uniform distribution of small disc-shaped spicules, and the presence of paired dorsal mesenteric filaments only. I am convinced by examination of the materials of the Cornulariidae and Xeniidae in my hand that this procedure is truly adequate. Of the allied genera, sarcothelia VerRIL (1928) which has no spicule may be referred to the genus Anthelia.

*Contributions from the Seto Marine Biological Laboratory, No. 144.

Publ. Seto Mar. Biol. Lab., I (3) 1950. 


\section{Anthelia formosana, n. sp.}

(Fig. 1)

From a rather thin flat basal membrane, about 1 to $3 \mathrm{~mm}$ in thickness, spreading over sponges or any other solid substratum, numerous zooids arise with their bases very close together. When alive, they are bluish white in colour, but turn into creamy white after preservation in formalin or alcohol.

Polyps generally large, non-retractile and in a given area of stolon vary greatly in number as well as in size. They are cylindrical, tapering gradually up to the slightly narrower but not well-defined neck. A full-grown polyp averages 10 to $20 \mathrm{~mm}$ in length, excluding the tentacles, and 2 to $3 \mathrm{~mm}$ in diameter at the base, with very thick body=walls, without any longitudinal grooves. Mouth slit-like, $0.2 \mathrm{~mm}$ in
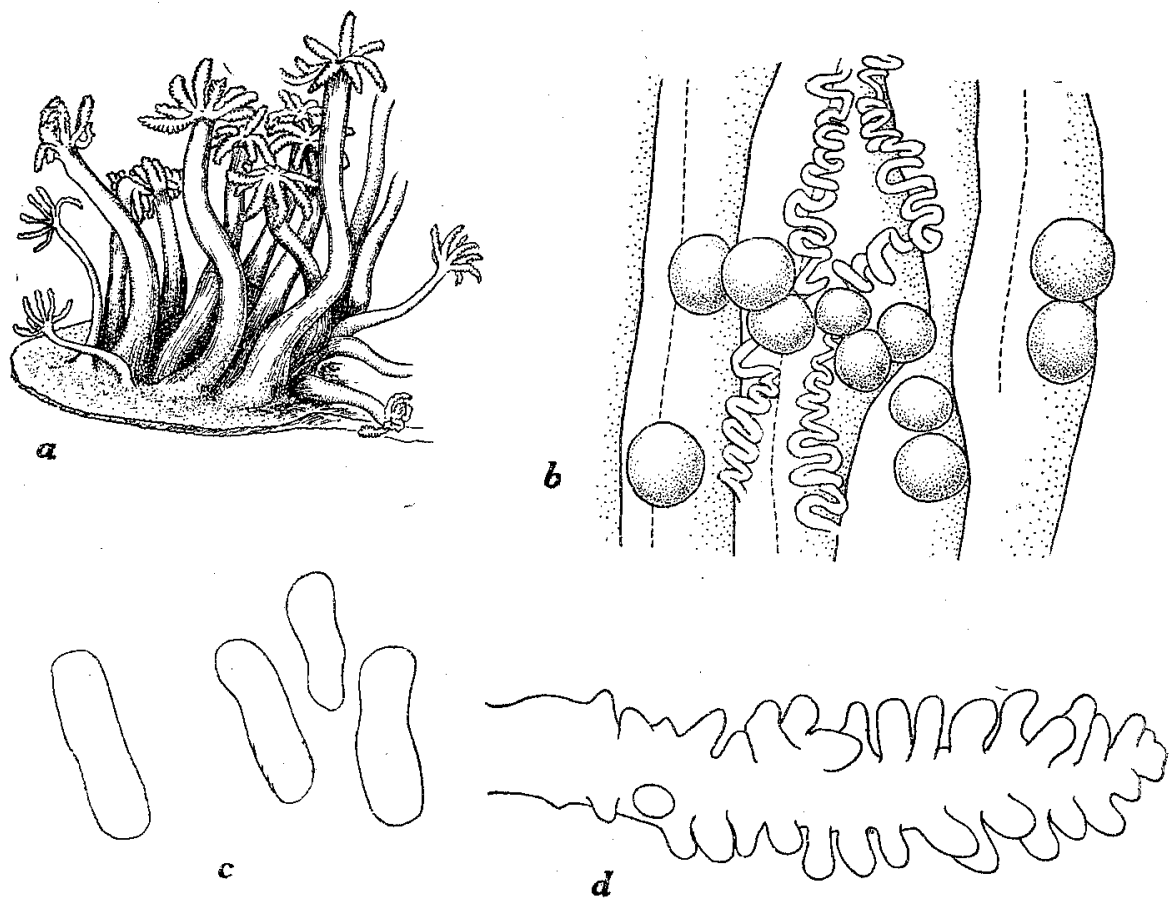

Fig. 1. Anthelia formosana n. sp. $a, \mathrm{~A}$ part of colony, $\times 2 ; b$, inner wall of basal part of coelenteric cavity, with paired dorsal mesenteric filaments and ripe eggs, $\times 12 ; c$, spicules (left one on stolons and right three on tentacles) $\times 500 ; d$, tentacle, ventral view, $\times 12$.

longest diameter, situated in the center of oral disc on a top of papilla-like hypostome. Tentacles stout, feathery, about $6.3 \mathrm{~mm}$ long and $0.8 \mathrm{~mm}$ wide at their base in a polyp of $20 \mathrm{~mm}$ long. Pinnules short, conical, in one row on either side of 
tentacles, leaving a broad bare streak on rachis of oral and aboral sice. They number 15 to 22 in a row, usually 18 . In longest one, it is $1 \mathrm{~mm} \mathrm{long}$ and $0 . t \mathrm{~mm}$ wide. Spicules evenly scattered all over the whole surface of polyps, but generally most crowded on the stolon. They are dusky white, minute flattened rod with a slight median constriction, about $0.02-0.036 \mathrm{~mm}$ long and $0.01-0.007 \mathrm{~mm}$ wide. Their surface is slightly roughened, but the margin is apparently smooth aud not beset with teeth.

Dissection shows the presence of a pair of dorsal mesenteric filaments running sinuously from top to base. Ripe eggs, about 20 in number, are found freely along the mesenteries, particularly near the base; they are about $0.45 \tilde{a}-0.7 \mathrm{~mm}$ in diameter.

The specimen comes nearest to Anthelia ternatana (Schenk, 1896) in the possession of a single row of pinnules on cach side of the tentacles. It is, however, distinguished by the shape and smaller dimension of the pinuules and spicules.

Occurrencs: This species is found luxuriantly in tide-pools at Garanbi, southernmost promontory of Formosa. Collectel by myself. Jume 13, 1938.

\section{Genus Xenia LAMARCK (1816)}

I have seen only two species belonging to the monomorphic xeniids, Xenia hicksoni Ashworth and $X$. kukenthati Roxas. It is quite likely that some other xeniid species occur in the southern part of the Japanese coast.

\section{Xenia hicksoni AsHWORTH}

(Fig. 2a)

This species has been frequently recorded from various localities of the IndoPacific region. To this species I refer several branching forms taken from Sibusi in $\mathrm{Kyusyu.}$

The material consists of three branched and a simple colonies. The colony arises from a common disc which branches into primary, secondary and occasionally tertiary branches. The main stalk is usually divided into two secondary branches near the base. The common basal disc is flat, rounded or irregular in outline, measuring about $30 \times 25 \mathrm{~mm}, 30 \times 23 \mathrm{~mm}, 20 \times 10 \mathrm{~mm}$ respectively. The largest stalk or branch is about $20 \mathrm{~mm}$ in length and $15 \mathrm{~mm}$ in diameter, and the secondary or tertiary branches do not exceed $1 \mathrm{~cm}$ in diameter.

Autozooids thickly set on top of branches, and in full-grown state 8-13 mm long and 2-2.5 mm wide. Tentacles 7-9 mm long, $1 \mathrm{~mm}$ wide and provided with two or three rows of pinnules on each side of rachis. On oral side of rachis, pinnules on both sides are widely separated basally, but in the distal half or one-third they come together leaving a slight, or even no, bare median space. Pinnules short, 
rounded papilla-like in shape in the contracted preserved specimen, and about $0.4 \mathrm{~mm}$ long and $0.18 \mathrm{~mm}$ wide in longest one. Their number in rows follows :-

$\begin{array}{lrrrrrr}\text { Inner row } & \ldots \ldots \ldots \ldots \ldots \ldots \ldots \ldots \ldots & 16 & 17 & 10 & 10 & 7 \\ \text { Median row } \ldots \ldots \ldots \ldots \ldots \ldots \ldots \ldots \ldots \ldots \ldots & 24 & 23 & 20 & 22 & 22 \\ \text { Outer row } & \ldots \ldots \ldots \ldots \ldots \ldots \ldots \ldots \ldots \ldots & 28 & 24 & 26 & 24 & 25\end{array}$

Spicules apparently absent, as in the type of Ashworth.

Occurrence: Four specimens collected by Dr. T. Komar from Sibusi, KagosimaKen, Kyusyu. April, 1934. This species has been recorded so far from Talisse Island, North Celebes (AsHwor'th, 1899), Massowa, Red Sea (Kükenthat, 1913) and Ghardaqa, Red Sea (GoHaR, 1940). The specimen described by Roxas (1933) from Mindoro Island, Philippines as $X$. hicksoni probably belongs to another species.

\section{Xenia kiükenthali RoXAS}

(Figs. 2d-g and 3a)

In superficial appearance, this specimen closely resembles the above-mentioned $X$. hicksoni, both bearing the branched stalk, but it is clearly distinguished from the latter by the characteristics of tentacles.

Colony small, branching, with small polyps. Common base usually low, $r$ unded in outline and measured about 10 to $30 \mathrm{~mm}$ in diameter. The trunk is cylindrical. about 9-12 mm long and 7-11 mm wide, and divided into two or more short branches bearing polyps on the top. Primary and secondary branches also cylindrical, about 5-20 mm long and 5-10mm wide or less. The whole colony from base to top of highest branch may measure up to $35 \mathrm{~mm}$. Colour in life bluish white, but turn into snowy white after preservation in formalin or alcohol.

Polyps rather short, about 5-12 mm long, 1-2 mm wide, with bodies thin and transparent in spirit. Tentacles short, apically rounded and about $3-4 \mathrm{~mm}$ long and $0.5-0.6 \mathrm{~mm}$ wide at base. They are provided with two rows of low wartlike pinnules on either side of a wide median bare streak. Outer row of pinnules usually numbers 10-12. Pinnules of inner row, which are hardly recognizable at base, more widely separated and lower than those of outer row. They number up to 8 in a row ; 2-4 pinnules at the distal part are more distinct than others, and those near the basal part are hardly recognized and may be absent. Largest one measures about $0.22 \mathrm{~mm}$ long, $0.26 \mathrm{~mm}$ wide at base. Spicules absent.

Occurrence: This species is commonly found on stones just below low tide level in the environs of Tomioka, Amakusa Island, Kumamoto-Ken. Previously recorded from Puerto Galera, Mindoro Island of the Philippines (Roxas, 1933). 

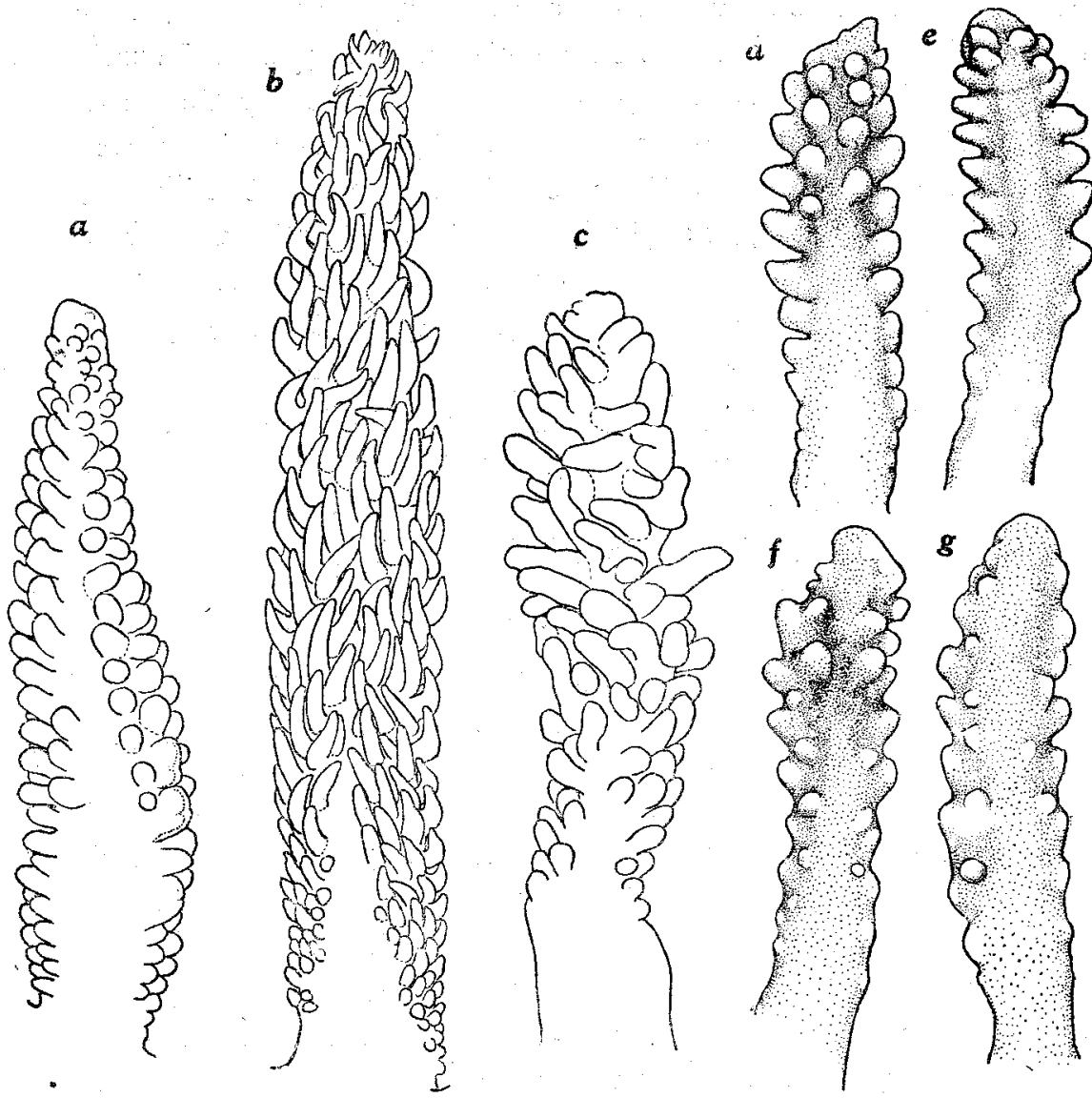

Fig, 2. Tentacles of Xenia hicksoni (a), Heteroxenia pinnata (b), Heteroxenia elisabethae $(c)$ and Xenic kükenthali $(d-g$,$) ventral view. [a-b, \times 12, c-g, \times 15$. $]$

\section{Genus Heteroxenia KöLLIKER (1875)}

The species problem in the Xeniidae, especially in reference to the specific characters, polyp dimorphism and the retractility, has been discussed by many authors for a number of years, but still it remains unsettled as a subject of considerable controversy. Among early works, the excellent studies by Hickson (1931) and Gohar (1940) have contributed much to our knowledge on this problem, so. that further discussion may be almost superfluous.

The principal distinctive characters of the species belonging to the genera, Xenia, Heteroxenia and allies, such as the form of colony, the shape, arrangement and number of pinnules, are highly variable according to the state of contraction by preservation and to the degree of growth, and are very unreliable for specific 
distinction. As pointed out by HICKsON and GOHAR, such morphological characters afford no reliable criterion for spe cifindisctiction, when preserved specimens alone are available. The physiological peculiarities as proposed by GoHAR (1940), such as the rate of pulsation, the degree of contractility and retracting power, and the time of breeding season, are certainly reliable to some extent. However, they are hardly available to anybody, except when the circumstance is most favorable.

It is futile to lay too much stress to such variable features as the characters of pinnules, spicules and others. Nevertheless, they are of some systematic value, if considered with some reservation and especially if a careful comparative study of a large number of living and preserved specimens is made. Possibly the effect of preservatives is somewhat different from species to species.

\section{Heteroxenia elisabethae KöLLIKER}

(Fig. 2c)

To this species I refer a number of specimens collected in Formosa which have four regular rows of pinnules on the tentasles. The usual number of pinnule rows in this species is stated by most previous authors to be 3 or 4 .

Preserved colonies with simple columnar stalk, 20-27 mm in height and 14-19 $\mathrm{mm}$ in basal diameter. Slightly expanded terminal disc, i.e. capitulum from which anthocodiae arise is about $10-22 \mathrm{~mm}$ in diameter. Autozooids closely set, with the stalk 5-13 $\mathrm{mm}$ long and $1.5-3 \mathrm{~mm}$ in diameter. Tentacles short, narrow, 4-6 mm long and about $0.35 \mathrm{~mm}$ wide at base, with three (at times four in the middle) rows of pinnules on each side of a median bare streak of oral surface. Pimules 14-17 in a row, elongate, fingerlike and rounded at end, except for a few wartlike ones at the proximal end. Those towards the middle part of tentasles measure about $0.5-0.6 \mathrm{~mm}$ long and 0.17-0.2 mm wide at base. They are closely set, and rather irregularly arranged in oblique rows. Base of tentacles on eash side devoid of pinnules. Siphonozooids filling up all gaps among autozooids, about $3 \mathrm{~mm}$ long and $0.5 \mathrm{~mm}$ in diameter. Spicules numerous, round to oval or oblong and $0.02 \times(0.009-0.014) \mathrm{mm}$ in size.

The specimens are much contrasted probably owing to the bad preservation.

Occurrence: Luxuriantly growing in tide-pools at Garanbi, Formosa. Collected by myself. June 13, 1938. As to its distribution refer to HICKson (1931).

\section{Heteroxenia pinnata RoXAS}

(Fig. 2b)

I (HIRo, 1937) have provisionally referrer the dimorphic xeniid occurring abundantly in the Palao Islands to Heteroxenia elisabethae, in accordance with Hick- 
son's suggestion to reduce the species which had been separately described solely on the basis of some unreliable morphological characters. On careful re-examination of the preserved materials from Palao, in comparison with the above-mentioned Formosan specimens, some remarkable differences between have been revealed. Although I am well aware of the variation of the characters of xeniids, yet I do not take the view that the peculiarities shown in these specimens are all due to contraction. Especially, the form and arrangement of pinnules of the tentacles and the low power of contraction of polyps are the most characteristic, as compared with those of the above-mentioned H. elisabethae and others. In this respect the specimens from Palao come nearest to $H$. pinnata described by Roxas (1933) from the Philippines among all the known species. Some differences between his specimens and mine are found, but all of the alleged differences seem to me of little systematic value.

Colony large, with a thick, tall columnar stalk, about 30-40 mm long and 20$30 \mathrm{~mm}$ in diameter. Average sizes of larger zooids are: Autozooids $30 \mathrm{~mm}$ long, $4 \mathrm{~mm}$ wide, and siphonozooids $3-4 \mathrm{~mm}$ long, 1-1.5 mm wide. Tentacles long, pointed at end, measuring about $10-16.5 \mathrm{~mm}$ long and $1.35 \mathrm{~mm}$ wide at base. In full-sized tentacles, there are usually four to five rows of pinuules on each side, with a broad bare streak hetween them. In a Iongitudinal row about 20-28 pinnules may be counted, though the number is variable according to the size of tentacle. Pinnules usually elongate, sharply pointed, and about $0.7-0.88 \mathrm{~mm}$ long and $0.2-0.23 \mathrm{~mm}$ wide at base; those at the proximal part are, however, somewhat wartlike. Spicules abundant in all parts of stalk and zooids, oval to round dises, measuring about 0.02 $0.024 \mathrm{~mm}$ long and $0.01-0.014 \mathrm{~mm}$ wide.

In the original description of $H$. pinnatx, Roxas (1933) says that the tentacles are relatively short. However, in their actual size ( $8 \mathrm{~mm}$ in Roxas' and 10-16.5 mm in mine) they are decidedly much larger than those in any other described species. According to previous descriptions of $H$. elisabethae, such as AsHworth (1899), THOMson and Henderson (1905), CylKowsKi (1911), HiCKson (1931), Roxas (1933) and others, the usual number of pinnules in a row is 3 or 4 , but exceptionally 2 or 5 . It is, therefore, clear that the separation of $H$. ashworthi from $H$. elisabethae as proposed by KüKEnThal (1902), only on the basis of bearing 3 pinnules in a row instead of 4 , is unsound. It is, however, even more unsound to refer the present $H$. pinnato to a variety of $H$. elisabethae, since in the present specimens as well as Roxas' type the usual number of pinnules in a row of the full-grown tentasles is not less than 4 but mostly 5 . This is more strengthened by the fact that even in KüLLIKER's gigantic type specimen of $H$. elisabethae (namely $40-55 \mathrm{~mm}$ in longest autozooid and $15 \mathrm{~mm}$ in longest tentacle), the pinnules were arranged only in 4 rows on each side. The dimensions of all parts of the colony were not much different between those of the living and preserved condition despite the prolonged immersion in preservative. This 
may account for the present specimens to have a relatively feeble power of contraction, as compared with the similarly preserved Formosan specimens of $H$. eliszbethae. After long consideration, I thought it best to retain Roxas' H. pinnata, as distinct from $H$. elisabethae.

Occurrence: Commonly occurs on the reef flat of Korror Island in the Palao Islands. Collected by myself. August-November, 1934. Previously recorded from Puerto Galera, Mindoro Island, where this species is the most abundant among all Heteroxenia (RoxAs, 1933).

\section{Genus Cespitularia MILnE-EDwaRds (1857)}

The definition of this genus is given by MACFAdYen (1936, p. 26) as follows:-"Xeniids with dendritic branching, and no sharply-defined margin to the capitulum, the polyps arising not only on the summit of the branches, but in gradually diminishing numbers down'their sides. Colonies typically soft, and with weak or no spiculation. The spicules, if present, are small discs, irregular ovals, or biscuitshaped."

This definition has, however, to be slightly modified to include the species $C$. stolonifera with somewhat membranous stolon and to exclude Efflatounaria, a genus with retractile polyps which was recently proposed by GoHAR (1939). Thus, the following generic diagnosis is proposed :

Xeniids with branched or dendritically membranous syndete, from the siles and summits of which non-retractile polyps arise at different levels. Capitulum not sharply defined from syndete. Spicules either minute oval or round dises or entirely absent.

\section{Cespitularia taeniata MAX}

(Fig. $3 \mathrm{~b}, \mathrm{c}$ )

To this species I refer three colonies attached to dead coral branches and shells collected in Tanabe Bay, Kii Province. In the largest one of them, 6 short main stems arise from an almost rounded common basal dise $(33 \times 34 \mathrm{~mm})$ and each stem branches into two to four primary branches, and many secondary and tertiary branchlets. Summits of the terminal branches are subequal in height, rounded in outline, the total length from base to top of branches being $27-33 \mathrm{~mm}$, though somewhat contracted. Terminal polyp-bearing branches are about $18 \mathrm{~mm}$ in height and 8-10 $\mathrm{mm}$ in diameter. The other specimens are about $15 \times 27 \mathrm{~mm}$ and $20 \times 26 \mathrm{~mm}$ respectively in the size of basal attachment, and they are both about $25 \mathrm{~mm}$ in height. All of them are yellowish white in the preserved state. 
Polyps somewhat contracted, but not retractile, and with tentacles up to $1.5 \mathrm{~mm}$ long and $1 \mathrm{~mm}$ wide. Pinnules arè arranged in a single row of 10-12 on each side of the tentacles; they are longest in the middle part, where they are up to $0.35 \mathrm{~mm}$ long and $0.17 \mathrm{~mm}$ in basal width.

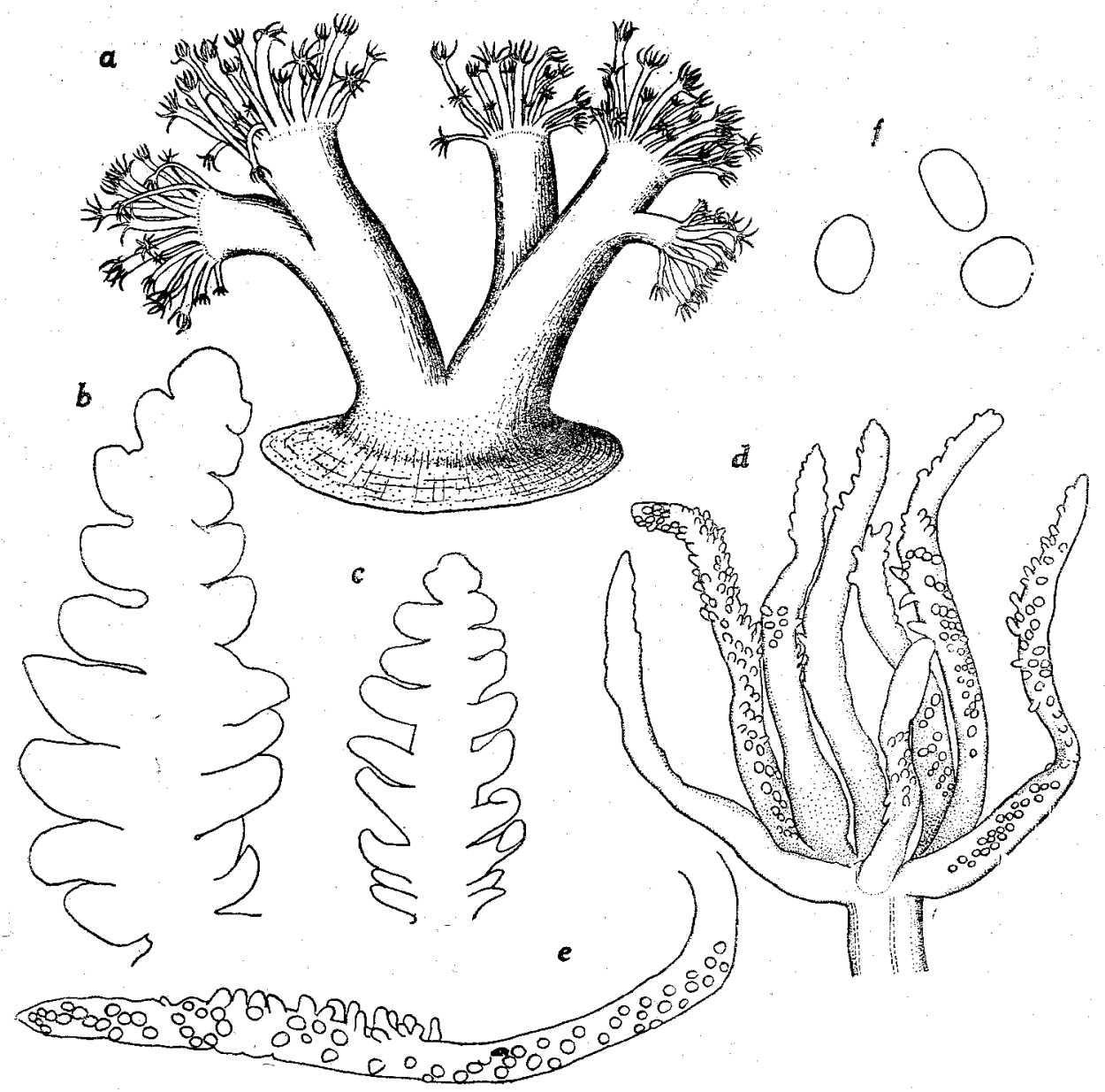

Fig. 3. a. A colony of Xenia kükenthali, $\times 1 ; b$, tẹtacle of Cespilularia taeriatä, $\times 33$; $c$, the same, $\times 27$; $d$, polyp of Cespitularia stolonifera, $\times 12$; $e$, tentacle , of $C$. stolonifera, lateral view (somewhat distorted distally), $\times 67 ; f$, spicules on tentacle of $C$. stolonifera, $\times 500$.

Spicules are entirely absent.

Occurrence: Ezura, in Tanabe Bay, Wakayama-Ken. Collected by myself. August 8, 1939. Previously recorded from Mozambique, Indian Ocean (MAY, 1900) and Sulu Archipelago ( $6^{\circ} 7.5^{\prime} \mathrm{N}, 120^{\circ} 26^{\prime} \mathrm{E}$ ) (THomson and DEAN, 1931). 


\section{Cespitularia stolonifera GOHAR}

(Fig. 3d-f)

A piece of large branched colonies of a xeniid, which I brought back from my collecting trip to Formosa in 1938, is obviously referable to this species recently described by Gohar (1938). In the living condition, as I remember, the colony was much larger than the specimen now in my possession, which is only a part of the colony. The actual size of the entire colony is now obscure.

As far as the present specimen is concerned, the colony consists of a large thin basal membrane spreading over the surface of a deal coral block, on which here and there a number of upright primary branches of different sizes stand. All the branches bear long polyps dispersed on the whole surface. The largest branch measures about $16 \mathrm{~mm}$ in height and $10 \mathrm{~mm}$ in basal diameter. Each of the branches gives rise to a few secondary branches.

The polyps arise from all branches and also from the basal membrane at different levels. Most of the polyps arising from the tip of branches are crowded together, while those standing on the sides of branches and on the basal membrane are sparse; but of ten 2 or 3 are grouped on a slight elevation which may be a bud of new branches. Each polyp is slender all throughout, growing up to $10 \mathrm{~mm}$ long, excluding the tentacles, and $0.5-1 \mathrm{~mm}$ in diameter. The shortest one is about $4 \mathrm{~mm}$ long. The polyp-body is provided with 8 shallow but distinct longitudinal grooves free of spicules along the lines of attachment of mesenteries. The oral dise is very narrow, with a relatively large hypostome.

Tentacles fingerlike, cylindrical, slender, of almost the same diameter from base to top ; average size--5 $\mathrm{mm}$ long and $0.25-0.35 \mathrm{~mm}$ in diameter. Piunules somewhat damaged, fragil and strongly contracted, in spite of rather good preservation. They are low and almost wartlike, except in the distal two-thirds or one-third, where they are more or less elongate, about $0.17 \mathrm{~mm}$ long and $0.07 \mathrm{~mm}$ wide, and nearly rounded at tips; they are arranged roughly in three longitudinal rows, leaving a narrow space between at the base. There are about 22 to 27 pinnules in a row.

Spicules very numerous on branches, polyp-body and tentacles, but apparently absent in pinnules, at least at their tips. In the basal membrane they are rather sparse. They are mostly small round dises (about $0.015 \mathrm{~mm}$ in diameter) and rarely oval or oblong disc (about $0.018-9.012 \mathrm{~mm}$ in size).

Occurrence: In tide-pools at Garanbi, Formosa. Collected by myself. June 13, 1938. Caphyra- or Lissocarcinus-like small crabs were found living among the polyps of the colony. Previously recorded from Amboina by WRIGIT and STUDER (1889) under the name of Xenia elongata DANA which name was recently corrected as Cespitularia stolonifera (n. sp.) by GoHAR (1938). 


\section{LITERATURE}

Ashworth, J. H. 1899. The structure of Xenia hicksoni, nov. sp., with some observations on Heteroxenia elizabethae, Kölliker. Quart. Journ. Micros. Sei., N.S., vol. 42 , pt. 8. pp. $245-304$.

Brundin, J. A.Z. 1896. Alcyonarien aus der Zoologischen Museums in Uppsala. Bih. svensk. Vetensk.-Akad. Handl., Bd. 22, Afd. 4, no. 3, pp. 1-22.

Cylkowski, P. 1911. Untersuchungen über den Dimorphismus bei den Alcyonarien. Inaugural-Dissertation, Breslau, pp. 1-47.

GoHAR, H. A. F. 1938. On a new species of Cespitularia and two invalid species of Xenia and Clavulcria. Proc. Zool. Soc. London, ser. B, vol. 108 pt. 3, pp, $483-487$.

— 1939. On a new xeniid genus Efflatounaria. Ann. Mag. Nat. Hist. ser. 11, vol. 3, pp. 32-36.

- 1940. Studies on the Xeniidae of the Red Sea. Publ. Mar. Biol. Sta. Ghardaqa (Red Sea), no. 2, pp. 25-118.

$\mathrm{H}^{\mathrm{I}}$ CKSON, S. J. 1931. The Alcyonarian family Xeniidae, with a revision of the genera and species. Great Barr. Reef Exped., Sci. Rep., vol. 4, no. 5, pp. $137-179$.

Hiro (=UTINomi , F. 1937. Observations on the Alcyonarian Heteroxenia elizabethae Kölliker, Annot. Zool. Japon., vol. 16, no. 3, pp. 237-244.

Kölliker, A. 1875. Die Pennatulide Umbelluld und zwei neue Typen der Alcyonarien. Festschr. phys. -med. Ges. in Würzburg, pp. 1-23.

Kükenthat, W. 1902. Versuch einer Revision der Alcyonarien. Die Familie der Xeniiden. Zool. Jahrb., Abt. Syst., Bd. 15, pp. 635-662.

— 1906. Japanische Alcyonaceen. Beitr. zur Naturg. Ostasiens. Herausgegeb. von Dr. F. Doflein. Abh. K. Bayer Akad. Wiss. II. Kl.-Suppl. Bd. 1, Abt. 1, pp. 1-86.

- 1913. Alcyonaria des Roten Meeres. Exp. S. M. Schiff "Pola" in des Roten Meer. Denkschr. Akad. Wiss. Wien, Bd. 89, pp. 1-33.

Macfadyen, L. M. I. 1936. Alcyonaria (Stolonifera, Alcyonacea, Telestacea and Gorgonacea). Great Barr. Reef Exped., Sci. Rep., vol. 5, no. 2, pp. 19-71.

MaY, W. 1900. Beiträge zur Systematik und Chorologie der Alcyonaceen. Jena. Zeit. Naturw., Bd. 33, N. F., pp. 1-180.

Roxas, H. A. 1933. Philippine Alcyouaria. The families Cornulariidae and Xeniidae. Philip. Journ. Sei., vol. 50, no. 1, pp. 49-110.

Schenk, A. 1897. Clavulariiden, Xeniiden und Alcyoniiden von Ternate. Abh. Senckenb, naturf. Ges. Frankfurt, Bd. 23, pp. 41-80.

Thomson, A. J. and L. M. I. DeAN (=MAcFAdYEN) 1931. The Alcyonacea of the Siboga Expedition, with an appendum to the Gorgonacea. Siboga-Expeditie, mon. $13 \mathrm{~d}, \mathrm{pp} .1-227$.

Thomson, A. J. and W. D. Henderson 1906. The marine fauna of Zanzibar and British East Africa, etc. Alcyonaria. Proc. Zool. Soc. London, 1906, pp. $393-443$.

Verrill, A. E. 1928. Hawaiian shallow water Anthozoa. Bernice P. Bishop Mus., Bull. 49. pp. 1-30.

WRIght, E. P. and Th. STuder, 1889. Alcyonaria. "Challenger" reports, Zool., vol. 31 , pp. 1-314. 